\title{
Protein Helix
}

National Cancer Institute

\section{Source}

National Cancer Institute. Protein Helix. NCI Thesaurus. Code C48043.

A protein secondary structure motif. Amino acids are arranged in a right-handed rod like structure stabilized by hydrogen bonds between the $\mathrm{C}=\mathrm{O}$ and the $\mathrm{N}-\mathrm{H}$ groups of the main chain. Types include:alpha-helix, 3.10 helix and pi-helix. 